\title{
PREDATORY ACTIVITY OF Arthrobotrys oligospora AND Duddingtonia flagrans ON PRE-PARASITIC LARVAL STAGES OF CYATHOSTOMINAE UNDER DIFFERENT CONSTANT TEMPERATURES
}

\author{
ATIVIDADE PREDATÓRIA DE Arthrobotrys oligospora E Duddingtonia flagrans NOS ESTÁDIOS \\ LARVARES PRÉ-PARASÍTICOS DE CYATHOSTOMINAE SOB DIFERENTES TEMPERATURAS \\ CONSTANTES
}

\author{
Clóvis de Paula Santos ${ }^{1}$ Terezinha Padilha ${ }^{2}$ Maria de Lurdes de Azevedo Rodrigues ${ }^{3}$
}

\section{SUMMARY}

The effect of different temperatures on the predatory activity of Arthrobotrys oligospora and Duddingtonia flagrans on the free-living larval stages of cyathostomes were evaluated in an experiment where feces of horses containing the parasites' eggs were treated with these fungi and incubated under different constant temperatures $\left(10^{\circ} \mathrm{C}, 15^{\circ} \mathrm{C}, 20^{\circ} \mathrm{C}, 25^{\circ} \mathrm{C}\right.$ and $\left.30^{\circ} \mathrm{C}\right)$. The results indicated that the optimum temperature for egg development was $25^{\circ} \mathrm{C}$. At $10^{\circ} \mathrm{C}$ the number of $L_{3}$ recovered was practically zero, and at $15^{\circ} \mathrm{C}$ and $20^{\circ} \mathrm{C}$, the percentage of larvae recovered was less than $3 \%$ of the total number of eggs per gram of feces. When these cultures subsequently were incubated for an additional period of 14 days at $27^{\circ} \mathrm{C}$, they allowed the development of $L_{3}$. In all the cultures inoculated with fungi a significant reduction in the number of larvae was observed. When incubated at $25^{\circ} \mathrm{C}$ or $30^{\circ} \mathrm{C}$, the fungi caused reductions above $90 \%$, in the number of $L_{3}$. The samples cultivated at $10^{\circ} \mathrm{C}, 15^{\circ} \mathrm{C}$, $20^{\circ} \mathrm{C}, 25^{\circ} \mathrm{C}$ and $30^{\circ} \mathrm{C}$, when incubated for an additional period of 14 days at $27^{\circ} \mathrm{C}$ the reduction percentage of larvae was above $90 \%$ for A. oligospora. However, the same did not occur for $\boldsymbol{D}$. flagrans. Here a reduction percentage between $47.5 \%$ and $41.8 \%$ was recorded when the cultures were incubated at $10^{\circ} \mathrm{C}$ and $20^{\circ} \mathrm{C}$, respectively. The two species of fungi tested showed to be efficient in reducing the number of $L_{3}$ when mixed with equine feces and maintained at the same temperature for the development of larval pre-parasitic stages of cyathostomes.

Key words: Arthrobotrys oligospora, Duddingtonia flagrans, nematophagous fungi, cyathostominae, biological control.

RESUMO

A atividade predatória de fungos nematófagos e o desenvolvimento de estádios pré-parasitários de nematódeos

\begin{abstract}
estrongilídeos são influenciados pela temperatura. O efeito de diferentes temperaturas constantes na atividade predatória dos fungos Arthrobotrys oligospora e Duddingtonia flagrans sobre as fases larvares de vida livre dos nematódeos ciatostomíneos foi avaliado em um experimento onde fezes de cavalos contendo ovos de parasitos foram tratadas com fungos e incubadas em diferentes temperaturas constantes $\left(10^{\circ} \mathrm{C}, 15^{\circ} \mathrm{C}, 20^{\circ} \mathrm{C}, 25^{\circ} \mathrm{C} e\right.$ $30^{\circ} \mathrm{C}$ ). Os resultados indicaram que a temperatura ótima de desenvolvimento de ovo até $L_{3}$ foi de $25^{\circ} \mathrm{C}$. A $10^{\circ} \mathrm{C}$ o número de $L_{3}$ recuperado foi praticamente zero e a $15^{\circ} \mathrm{C}$ e $20^{\circ} \mathrm{C}$ os percentuais obtidos foram inferiores a $3 \%$ do total do número de ovos por grama de fezes. Quando estes cultivos foram incubados por um período adicional de 14 dias à $27^{\circ} \mathrm{C}$ permitiram o desenvolvimento até $L_{3}$. Em todos os cultivos inoculados com fungos, quando as larvas estavam presentes, houve redução significativa no número de larvas atribuído à ação predatória dos fungos. A $25^{\circ} \mathrm{C}$ e $30^{\circ} \mathrm{C}$ os fungos ocasionaram reduçóes acima de $90 \%$ no número de $\mathrm{L}_{3}$. Os cultivos mantidos à $10^{\circ} \mathrm{C}, 15^{\circ} \mathrm{C}, 20^{\circ} \mathrm{C}$, $25^{\circ} \mathrm{C}$ e $30^{\circ} \mathrm{C}$ quando incubados por um período adicional de 14 dias na temperatura controle, mantiveram percentuais de redução larvar superior a $90 \%$ para o fungo A. oligospora, o mesmo não ocorrendo para $D$. flagrans, que apresentou percentuais de $47,5 \%$ e $41,8 \%$ quando estimulado a $10^{\circ} \mathrm{C}$ e $20^{\circ} \mathrm{C}$, respectivamente. Esses fungos demonstraram ser eficientes na redução do número de $L_{3}$ quando adicionados a fezes de eqüinos nas mesmas temperaturas ideais para o desenvolvimento dos estádios larvares pré-parasitários.
\end{abstract}

$\begin{array}{lll}\text { Palavras-chave: } & \begin{array}{l}\text { Arthrobotrys oligospora, Duddingtonia } \\ \text { flagrans }\end{array} & \begin{array}{l}\text { fungos } \\ \text { nematófagos, }\end{array}\end{array}$ cyathostominae, controle biológico.

\section{INTRODUCTION}

Anthelminthic resistance in small strongyles in horses, primarily against

\footnotetext{
${ }^{1}$ Universidade Estadual do Norte Fluminnese, Centro de Biociências e Biotecnologia, Laboratório de Biologia Celular e Tecidual, Av. Alberto Lamego, 2000, Horto, 28015-620, Campos dos Goytacazes, RJ. E-mail: cps@uenf.br. Autor para correspondência.

${ }^{2}$ USDA-ARS, Embrapa-LABEX, ANRI-IDRL.

${ }^{3}$ Departamento de Parasitologia Animal do Instituto de Biologia da Universidade Federal Rural do Rio de Janeiro. Recebido para publicação em 11.05.00. Aprovado em 07.03.01
} 
benzimidazole, is well-documented and becoming common in several regions (BJØRN et al., 1991; BOERSEMA et al., 1991). Grazing practices and mechanical pasture hygiene have been recommended as an aid to reduce anthelmintic use to control cyathostomes (HERD, 1993). Biological control of free-living stages by the use of microfungi might be an alternative to integrate into future control practices of this horse helminthosis. The potential of this group of organisms to reduce free living stages of parasitic nematodes, which have similar cycle on pasture, has been well demonstrated at laboratory as well as field experiments (LARSEN, 1999).

The effect of nematophagous fungi against free-living stages of cysthostomes has been examined in a few studies. Arthrobotrys oligospora and Duddingtonia flagrans, two nematophagous fungi which both produce hyphal traps significantly reduce the number of infective larvae in fecal cultures as well as in pasture (BIRD \& HERD, 1995; CHARLES et al., 1995, FERNÁNDEZ et al., 1997). LARSEN et al., (1995) demonstrated that a Danish isolate of $\boldsymbol{D}$. flagrans was able to survive gut passage and subsequently trap larvae in horse feces. When tested in a field experiment, a daily dose of chlamydospores of $\boldsymbol{D}$. flagrans mixed in a feed supplement and given to horses for a period of three months reduced significantly the transmission of larvae from fecal pats to herbage (LARSEN et al., 1996). FERNÁNDEZ et al., (1997) showed that when fungal spores were fed to horses for five consecutive days at a dose rate from $10^{6}$ to $5 \times 10^{6}$ it gave a high and significant reduction in number of infective strongyle larvae.

For the Nematophagous fungi be used in biological control of horse nematodes, it has to act on fecal pats at different environmental conditions. Various morphogenic processes by nematophagous fungi, such us trap formation, are influenced by environmental conditions especially temperature (GRØNVOLD, 1989). The present paper focuses on the effect of different constant temperatures on the trapping efficacy of $\boldsymbol{A}$. oligospora and $\boldsymbol{D}$. flagrans against pre-parasitic larvae of cyathostomes in fecal culture.

\section{MATERIALS AND METHODS}

Cultures of $\boldsymbol{A}$. oligospora (University of Guelph number 80) and $\boldsymbol{D}$. flagrans (University of Guelph number 126, synonyms Trichothecium flagrans and Arthrobotrys flagrans) used in this experiment were donated to our laboratory by Dr. Rupert Herd from Ohio State University. They were grown in corn meal agar (4\% agar) at room temperature of $20^{\circ} \mathrm{C}-27^{\circ} \mathrm{C}$. When fungi covered the whole surface of the plates, conidia and mycelial fragments of $\boldsymbol{A}$. oligospora were harvested by scraping the surface of the agar with the aid of a brush and by rinsing off the surface with distilled water. D. flagrans chlamydospores and mycelial fragments were recovered in the same manner as the conidia of A. oligospora. However, to isolate the chlamydospores from the washed material, the suspension was mixed with a pipette, it was aspirated and released vigorously during many times in order to get a maximum isolation of chlamydospores. The concentration of fungal units in the suspension was adjusted after counting using of a haemacytometer chamber.

Feces were collected per rectum of horses carrying a natural infection of strongyles nematodes, which were known to be predominantly cyathostomes (98\%) as determined through individual larval cultures. After thorough mixing and determination of number of egg per gram of feces (EPG), 90 aliquots of $4 \mathrm{~g}$ each were distributed into disposable plastic cups with $60 \mathrm{~m} \ell$ capacity. From those, 30 cultures were each treated with a $4 \mathrm{~m} \ell$ suspension of 2000 conidia of A. oligospora in distilled water/ml, another 30 cultures were each treated with $4 \mathrm{ml}$ of a suspension of chlamydospores of D. flagrans in distilled water/ml and the last 30 received $4 \mathrm{~m} \ell$ of distilled water only. Subsequently, the cultures were individually homogenized. Out of the 30 samples submitted to each treatment, 10 of them were incubated at $27^{\circ} \mathrm{C}$ and the other 20 were incubated at the test temperature. Each group of samples was placed in a tray containing a thin layer of water in the bottom. The tray was covered with a plastic film to prevent loss of moisture during the 14 days incubation period. After the incubation, 10 samples incubated at the control temperature and 10 samples incubated at the test temperature were baermanized. The other 10 samples, which were incubated at the test temperature, were transferred to the control temperature for an additional incubation for 14 days after which they were also baermanized to recover the infective larvae $\left(\mathrm{L}_{3}\right)$. Recovered $\mathrm{L}_{3}$ were fixed and preserved in formaline $10 \%$ for later quantification. This set-up was repeated five times, one for each of the five-test temperature studied: $10^{\circ} \mathrm{C}, 15^{\circ} \mathrm{C}, 20^{\circ} \mathrm{C}, 25^{\circ} \mathrm{C}$ and $30^{\circ} \mathrm{C}$.

The number of larvae recovered from the cultures were analyzed after logarithmic transformation using the equation $X=\log _{10}(x+1)$. In all the comparisons the Levine's test, analysis of variance and Tukey's test were used to the level of 
significance of 5\% (HENKEL, 1976; GLANTZ, 1992). For the analyses, the SPSS software, version 7.5 (SPSS, 1997) was used.

\section{RESULTS AND DISCUSSIONS}

A.oligospora and D. flagrans were both able to reduce the number of larvae in fecal cultures significantly. When added to feces and cultivated at $27^{\circ} \mathrm{C}$ a reduction of more than $90 \%$ in the number of infective larvae was observed (Table 1).

The number of infective larvae recovered at $10^{\circ} \mathrm{C}, 15^{\circ} \mathrm{C}$ and $20^{\circ} \mathrm{C}$ was significantly lower than the number recovered when samples were kept at $27^{\circ} \mathrm{C}$ (control temperature). Egg development up to infective stage at and below $20^{\circ} \mathrm{C}$ was less than $3 \%$ of the total number of EPG. Once cultures were reincubated at $27^{\circ} \mathrm{C}$ for an additional period of 14 days, development of infective larvae reached levels close to what was obtained at the control temperature (Table 1). Yields of infective larvae in temperatures below to $20^{\circ} \mathrm{C}$ were much lower as it was demonstrated in other studies (OGBOURNE, 1972; RUPASINGHE \& OGBOURNE, 1978; ENGLISH, $1979 ; \quad$ MFITILODZE \& HUTCHINSON, 1987).

MFITILODZE \& HUTCHINSON (1987), working with fecal samples of $5 \mathrm{~g}$ and $10 \mathrm{~g}$ observed that yields of infective larvae were much higher in samples with larger volume. They found that temperature and moisture interacted to affect both the rate of development and yields of infective larvae from horse feces. Larger fecal samples had protective effect in keeping the moisture contents and larval yields. In the present study, it was observed low percentage of egg, which developed up to infective stage in all cultures not treated with fungi (Table 1). This may relate to the low volume of fecal samples used. Since low numbers $\mathrm{L}_{3}$ were obtained at $10^{\circ} \mathrm{C}, 15^{\circ} \mathrm{C}$ and $20^{\circ} \mathrm{C}$, it was not possible to investigate the effect of temperature on the capacity of the fungi to act on the free living stages in the fecal environment, at least for a 14 day period. However, the results indicate that the maintenance of fungi at these temperatures for a 14 day period do not affect its predatory activity since they were, aside from D. flagrans kept at $10^{\circ} \mathrm{C}$, capable of reducing significantly the number of larvae once samples were transferred to $27^{\circ} \mathrm{C}$ and incubated for an additional 14 days.

The number of larvae recovered from the cultures treated with $\boldsymbol{D}$. flagrans at $10^{\circ} \mathrm{C}$ and $20^{\circ} \mathrm{C}$ and reincubated at $27^{\circ} \mathrm{C}$ where $47.5 \%$ and $41.8 \%$ of the number of larvae recovered from the samples treated only with distilled water (Table 1). Reductions in these temperatures due to the action of the fungi were expected to be higher, especially considering that reduction was almost $94 \%$ at $15^{\circ} \mathrm{C}$. These results could have been due to interaction between the incubation period and the ratio of chlamydospore per egg. In these cultures the incubation period was 28 days and the number of chlamydospore per egg was below one. In previous experiment conducted with the same isolates,

Table 1 - Mean number of infective cyathostome larvae recovered from faecal cultures submitted to five constant temperatures ( $\mathrm{x} \pm \mathrm{s}$.d.) and the percentage of egg which developed up to infective stage in each treatment (in parenthesis).

\begin{tabular}{|c|c|c|c|c|c|}
\hline \multirow[t]{2}{*}{ Experiment } & \multirow[t]{2}{*}{ Initial EPG } & \multirow[t]{2}{*}{ Temperatures } & \multicolumn{3}{|c|}{ Treatments } \\
\hline & & & Distilled water & A. oligospora & D. flagrans \\
\hline \multirow[t]{3}{*}{1} & 2165 & $\mathrm{CT}$ & $1074 \pm 506(49.6)$ & $42 \pm 50(1.9)$ & $37 \pm 20(1.7)$ \\
\hline & & TT $10^{\circ} \mathrm{C}$ & $0(0)$ & $1 \pm 0.8(0.05)$ & $3 \pm 8(0.1)$ \\
\hline & & $\mathrm{TT}+$ reincubation $\mathrm{CT}$ & $985 \pm 4(45.5)$ & $7 \pm 8(0.7)$ & $517 \pm 556(23.9)$ \\
\hline \multirow[t]{3}{*}{2} & 1033 & $\mathrm{CT}$ & $111 \pm 134(10.7)$ & $5 \pm 6(0.5)$ & $11 \pm 11(1.1)$ \\
\hline & & TT $15^{\circ} \mathrm{C}$ & $2 \pm 3(0.2)$ & $4 \pm 5(0.4)$ & $0(0)$ \\
\hline & & $\mathrm{TT}+$ reincubation $\mathrm{CT}$ & $161 \pm 65(15.6)$ & $7 \pm 6(0.7)$ & $10 \pm 11(0.9)$ \\
\hline \multirow[t]{3}{*}{3} & 3000 & CT & $1029 \pm 1004(34.3)$ & $30 \pm 25(1.0)$ & $29 \pm 21(0.96)$ \\
\hline & & TT $20^{\circ} \mathrm{C}$ & $10 \pm 16(0.3)$ & $8 \pm 8(0.26)$ & $80 \pm 71(2.7)$ \\
\hline & & $\mathrm{TT}+$ reincubation $\mathrm{CT}$ & $670 \pm 471(22.3)$ & $4 \pm 4(0.13)$ & $390 \pm 225(13.0)$ \\
\hline \multirow[t]{3}{*}{4} & 1200 & $\mathrm{CT}$ & $184 \pm 217(15.3)$ & $16 \pm 15(1.3)$ & $10 \pm 7(0.8)$ \\
\hline & & TT $25^{\circ} \mathrm{C}$ & $364 \pm 161(30.3)$ & $2 \pm 3(0.17)$ & $20 \pm 11(1.7)$ \\
\hline & & $\mathrm{TT}+$ reincubation $\mathrm{CT}$ & $263 \pm 177(21.9)$ & $11 \pm 9(0.92)$ & $12 \pm 12(1.0)$ \\
\hline \multirow[t]{3}{*}{5} & 1270 & $\mathrm{CT}$ & $910 \pm 389(71.7)$ & $20 \pm 16(1.6)$ & $25 \pm 19(1.97)$ \\
\hline & & TT $30^{\circ} \mathrm{C}$ & $620 \pm 243(48.8)$ & $60 \pm 43(4.7)$ & $33 \pm 15(2.6)$ \\
\hline & & $\mathrm{TT}+$ reincubation $\mathrm{CT}$ & $340 \pm 174(26.8)$ & $18 \pm 15(1.4)$ & $12 \pm 17(0.95)$ \\
\hline
\end{tabular}

EPG - Eggs per gram

CT - Control temperature of $27^{\circ} \mathrm{C}$

TT - Test temperature in each experiment

Ciência Rural, v. 31, n. 5, 2001. 
significant reduction of infective cyathostome larva was observed only when a concentration equal or higher than one chlamydospores per egg was used (BIRD, 1995). In the experiment conducted here, the dosages of chlamydospores were determined by gram of feces. After converting it to chlamydopores per egg of cyathostome, only at $10^{\circ} \mathrm{C}$ and $20^{\circ} \mathrm{C}$ was the ratio below one ( 0.92 and 0.67 , respectively). At the other test temperatures, the ratio chlamydospore: egg was above one $\left(1.94,1.67\right.$ and 1.57 at $15^{\circ} \mathrm{C}, 25^{\circ} \mathrm{C}$ and $30^{\circ} \mathrm{C}$, respectively). The same ratio chlamydospore: egg was present at the control temperature $\left(27^{\circ} \mathrm{C}\right)$ in the experiments run at $10^{\circ} \mathrm{C}$ and $20^{\circ} \mathrm{C}$ and the fungus was effective (reduction higher than $90 \%$ ), however the incubation time for the control cultures was half the time used to the cultures reincubated at $10^{\circ} \mathrm{C}$ and $20^{\circ} \mathrm{C}$. It may be possible that the low number at chlamydospores and the longer incubation period contributed low reduction of larval in those cultures. Besides, an experiment conducted in Denmark with seven isolates of $\boldsymbol{D}$. flagrans concluded that this fungus grows slowly at temperatures lower than $25^{\circ} \mathrm{C}$ (LARSEN, 1991) and optimal growth is obtained at $30^{\circ} \mathrm{C}$. When the isolates were studied at $10^{\circ} \mathrm{C}, 15^{\circ} \mathrm{C}$ and $20^{\circ} \mathrm{C}$, radial growth of the seven isolates was smaller when compared to the growth of one isolate of A. oligospora and two isolates of Arthrobotrys superba.

Both fungi tested species showed to be efficient in reducing the number of $\mathrm{L}_{3}$ when mixed with equine feces and maintained at the same temperature for the development of larval pre-parasitic stages of cyathostomes.

The similarity of temperature requirements for the action of these fungi and the development of free-living stages of these nematodes in the fecal environment, as well as the capacity of the fungus to resume growth after being kept at lower temperatures, could facilitate the development of this alternative to classical control using anthelmintics.

\section{REFERENCES}

BIRD, J. Effect of nematophagous fungi on the development of infective larvae of common endoparasites of horses, sheep and cattle. Columbus, Ohio, 1995. 95p. Thesis $(\mathrm{PhD})$ - The Ohio State University, 1995.

BIRD, J., HERD, R.P. In vitro assessment of two species of nematophagous fungi (Arthrobotrys oligospora and Arthrobotrys flagrans) to control the development of infective cyathostome larvae from naturally infected horses. Veterinary Parasitology, v.56, p.181-187, 1995.

BJØRN, H., SOMMER, C.H.R., SCHOUGÅRD, H., et al. Resistance to benzimidazole anthelminthics in small strongyles (Cyathostominae) of horses in Denmark. Acta Veterinaria Scandinavica, v.32, p.253-260,1991.
BOERSEMA, J.H., BORGSTEEDE, F.H.M., EYSKER, M., et al. The prevalence of anthelmintic resistance of horse strongyles in the Netherlands. Veterinary Quarterly, v.13, p.209-217, 1991.

CHARLES, T.P., RODRIGUES, M. de L. de A., SANTOS, C. de P. Redução do número de larvas de Cyathostominae em fezes de eqüinos tratados com conídios de Arthrobotrys oligospora. Arquivo Brasileiro de Medicina Veterinária e Zootecnia, v.47, p.87-89, 1995

ENGLISH, A.W. The epidemiology of equine strongylosis in Southern Queensland. 1. The bionomics of the free-living stages in faeces and on pastures. Australian Veterinary Journal, v.55, p.299-304, 1979.

FERNÁNDEZ, A.S., LARSEN, M., NANSEN, P., et al. Effect of the nematode-trapping fungus Duddingtonia flagrans on the fre-living stages of horse parasitic nematodes: a plot study. Veterinary Parasitology, v.73, p.257-266, 1997.

GLANTZ, S.A. Primer of biostatistics. 3 ed. New York : Mc Graw Hill, 1992. 440p.

GRØNVOLD, J. Transmission of infective larvae of Ostertagia ostertagi and Cooperia onchophora (Trichostrongylidae: Nematoda). Copenhagen, Denmark, 1989. 93p. Thesis (PhD) The Royal Veterinary and Agricultural University, 1989.

HENKEL, R.E. Tests of significance. California : Sage QASS Series, Sage Publications, 1976. 92p.

HERD, R.P. Control strategies for ruminant and equine parasites to counter resistance, encystment and ecotoxicity in the USA. Veterinary Parasitology, v.48, p.327-336, 1993.

LARSEN, M. Studies on the capacity of microfungi to destroy animal parasitic nematode. Copenhagen, Denmark, 1991. 61p. Thesis $(\mathrm{PhD})$ - The Royal Veterinary and Agricultural University, 1991.

LARSEN, M. Biological control of helminths. International Journal for Parasitology, v.29, p.139-146, 1999.

LARSEN, M., NANSEN, P., HENRIKSEN, S.A., $\boldsymbol{e}$ t $\boldsymbol{a}$. Predacious activity of the nematode-trapping fungus Duddingtonia flagrans against cyathostome larvae in faeces after passage through the gastrointestinal tract of horses. Veterinary Parasitology, v.60, p.315-320, 1995.

LARSEN, M., NANSEN, P., GRØNDAHL, S.M., et al. The capacity of the fungus Duddingtonia flagrans to prevent strongyle infections in foals on pastures. Parasitology, v.113, p.1-6, 1996.

MFITILODZE, M.W., HUTCHINSON, G.W. Development and survival of free-living stages of equine strongyles under laboratory conditions. Veterinary Parasitology, v.23, p.121133, 1987.

OGBOURNE, C.P. Observation on the free-living stages of strongylid nematodes of horses. Parasitology, v.64, p.461477, 1972.

RUPASINGHE, D., OGBOURNE, C.P. Laboratory studies on the effect of temperature on the development of the freeliving stages of some strongylid nematodes of the horse. Zeits Parasitenkunde, v.55, p.249-253, 1978.

SPSS. Statistical Package for Social Science. Base for Windows. v.7.5. Chicago. 1997. 